\title{
Implementation of Lean Services in Hospitals To Improve The Efficiency of Patient Services in The Organization Of Health Social Security (BPJS)
}

\author{
Suhartini $^{1}$, E Yuliawati ${ }^{1}$, N Rahmawati $^{1}$ and D A H Syahputra ${ }^{1}$ \\ ${ }^{1}$ Industrial Engineering Department, Faculty of Industrial Technology, Institut Teknologi Adhi \\ Tama Surabaya, Indonesia \\ suhartini@itats.ac.id
}

\begin{abstract}
The hospital has a very vital role in efforts to improve the health status of all Indonesian people. When the process of serving a hospital is not effective and efficient, patients who can be referred to as customers from the hospital will feel the impact. Long processes and patients who are required to queue in each process results in patients having to wait a long time to get service. It is hoped that Lean will apply it to hospitals to improve the process so that it can provide optimal services, and at a lower cost. From the results of this study, the waste found in the service of The Organization of Health Social Security (BPJS) is waiting /delay \& defect. The impact of lean service implementation on the BPJS Health patient service process according to the process activity mapping, increasing the process cycle efficiency to $64 \%$, according to the supply chain response matrix is to add service facilities, and according to the quality filter mapping is to carry out routine control of the registration process and the amount of stock paper and printer.
\end{abstract}

\section{Introduction}

The hospital is currently a health facility that provides health facilities and infrastructure to the entire community has a very vital role in efforts to improve the health status of the entire community. The hospital is currently required to perform good services with standards that are appropriate and can be easily obtained by all levels of Indonesian society. When the process of serving a hospital is not effective and efficient, patients who can be referred to as customers from the hospital will feel the impact. Long processes and patients who are required to queue in each process results in patients having to wait a long time to get service.

Lean can be interpreted as a strategy for management and resources derived from management practices originating from Japan. Lean is an ongoing effort to reduce waste and increase added value (value added) of a product (goods / services) in order to provide value to customers (customer value) [1]. Lean has a respect to people philosophy and continuous improvement. In the process of outpatient, The Organization of Health Social Security services, there is still a long queue at each counter and there are still errors in the service process. It is hoped that Lean will apply it to hospitals to improve the process so that it can provide optimal services, and at a lower cost 


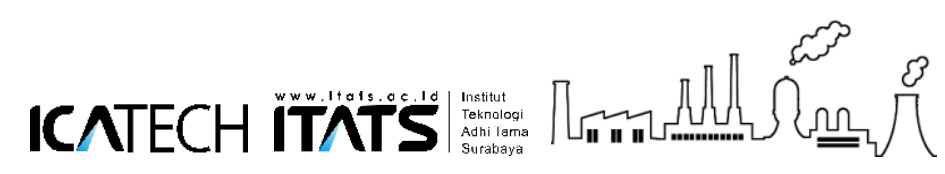

The $1^{\text {st }}$ International Conference on Advanced Engineering and Technology - 2018

\section{Literature Review}

\subsection{Lean and Waste}

Lean is a continuous effort to eliminate waste and increase value added (products and / or services) in order to provide value to customers (customer value). The goal of Lean itself is to continuously improve customer value through continuous improvement ratios between value added to waste (the value-to-waste ratio) (Gasperz, 2007). Waste can be defined as all work activities that do not create added value in the process of changing inputs to output along the value stream (the process for making, producing, and delivering products both goods and or services to the market). Based on the Lean perspective, all types of waste that occur throughout the value stream process, which transform inputs into outputs, must be eliminated in order to increase the value of the product (goods and or services) and then increase the customer value [2].

\subsection{Kinds of Activity and Value Stream Mapping (VSM)}

When talking about waste, it is necessary to have a clear definition of the types of activities that occur in a production system or in-service activities. Here are the types of activities that often occur in the process of production or service [3]: (1) Value Added Activity; (2) Non-Value-Added Activity; (3) Necessary non-Value-Added Activity. Value Stream Mapping is a mapping process tool that functions to identify the flow of material and information in the production process from materials to finished products. Value Stream Mapping is a visual method for mapping and information from each work station [4]. This Value Stream Mapping can be used as a starting point for companies to recognize waste and identify the causes [5].

Value stream analysis tools are used as a tool to map in detail the value stream that focuses on the value adding process. This detailed mapping can then be used to find the cause of the waste that occurs. There are seven types of detailed mapping tools that are most commonly used are [6]: (1) Process Activity Mapping; (2) Supply Chain Response Matrix; (3) Production Variety Funnel; (4) Quality Filter Mapping; (5) Demand amplification mapping; (6) Decision Point Analysis; (7) Physical Structure.

\section{Research Methodology}

In the steps that must be carried out in this study as well as identifying problems, conducting a literature review, collecting and processing data and analyzing the results of a study. and the last is to conclude the results of a research that has been done. The research method flowchart used in this study can be seen in Figure 1. 
RATECH ITATS'

The $1^{\text {st }}$ International Conference on Advanced Engineering and Technology - 2018

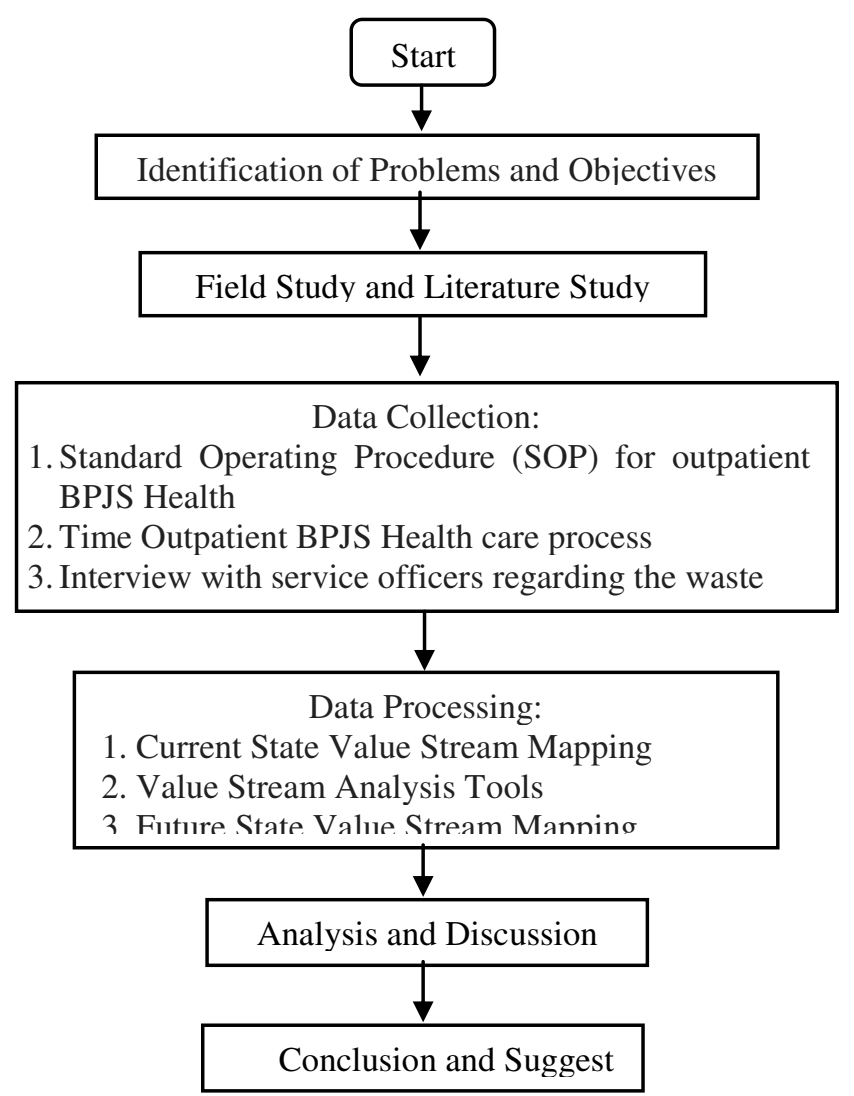

Figure 1. Flowchart of Research Methodology

\section{Result and Discussion}

\subsection{Data Process of Cycle Time}

The cycle time process data on the process flow of BPJS Health patient services is obtained from direct observation in the field by replicating 10 times. The main process in the patient's BPJS health service flow is the registration process at the registration counter, the file verification process at the validation counter, the process of inputting data into the SEP system, printing the SEP and combining referral letters, and legalizing files at the Health BPJS counter. The cycle time process data on the service flow of patients of Health BPJS are in the following Table 1:

Information:

Process $1=$ Customer Service

Process $2=$ Walk to the registration window

Process $3=$ Queue registration window

Process $4=$ Registration at the registration window

Process $5=$ Time to walk to the validation window

Process $6=$ Queue validation counter 


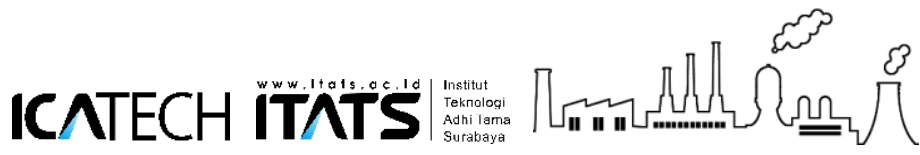

The $1^{\text {st }}$ International Conference on Advanced Engineering and Technology - 2018

Table 1. The Cycle Time Process of Out Patient Services in BPJS Health

\begin{tabular}{|c|c|c|c|c|c|c|c|c|c|c|c|c|c|}
\hline No. & $\begin{array}{c}\text { Proc } \\
\text { ess } 1 \\
\text { (s) }\end{array}$ & $\begin{array}{c}\text { Proc } \\
\text { ess } 2 \\
\text { (s) }\end{array}$ & $\begin{array}{c}\text { Proc } \\
\text { ess } 3 \\
\text { (s) }\end{array}$ & $\begin{array}{c}\text { Proc } \\
\text { ess } 4 \\
\text { (s) }\end{array}$ & $\begin{array}{c}\text { Proc } \\
\text { ess } 5 \\
\text { (s) }\end{array}$ & $\begin{array}{c}\text { Proc } \\
\text { ess } 6 \\
\text { (s) }\end{array}$ & $\begin{array}{c}\text { Proc } \\
\text { ess } 7 \\
\text { (s) }\end{array}$ & $\begin{array}{c}\text { Proc } \\
\text { ess } 8 \\
\text { (s) }\end{array}$ & $\begin{array}{c}\text { Proc } \\
\text { ess } 9 \\
\text { (s) }\end{array}$ & $\begin{array}{c}\text { Process } \\
10(\mathrm{~s})\end{array}$ & $\begin{array}{c}\text { Process } \\
11 \text { (s) }\end{array}$ & $\begin{array}{c}\text { Process } \\
12(\mathrm{~s})\end{array}$ & $\begin{array}{c}\text { Total } \\
\text { (s) }\end{array}$ \\
\hline 1. & 43 & 9 & 421 & 201 & 21 & 399 & 102 & 192 & 9 & 412 & 72 & 121 & 1993 \\
\hline 2. & 52 & 11 & 437 & 231 & 18 & 411 & 132 & 186 & 10 & 421 & 87 & 131 & 2127 \\
\hline 3. & 51 & 13 & 451 & 221 & 19 & 512 & 107 & 189 & 11 & 399 & 86 & 119 & 2178 \\
\hline 4. & 61 & 9 & 510 & 251 & 23 & 496 & 121 & 210 & 13 & 407 & 79 & 125 & 2305 \\
\hline 5. & 45 & 9 & 492 & 213 & 24 & 421 & 118 & 199 & 12 & 417 & 75 & 137 & 2162 \\
\hline 6. & 63 & 11 & 398 & 227 & 27 & 511 & 121 & 201 & 14 & 423 & 80 & 131 & 2207 \\
\hline 7. & 48 & 10 & 412 & 218 & 21 & 519 & 131 & 196 & 17 & 413 & 71 & 129 & 2185 \\
\hline 8. & 54 & 11 & 434 & 220 & 17 & 489 & 109 & 192 & 19 & 389 & 78 & 109 & 2121 \\
\hline 9. & 52 & 9 & 399 & 242 & 22 & 516 & 99 & 205 & 11 & 379 & 79 & 116 & 2129 \\
\hline 10. & 42 & 11 & 412 & 256 & 21 & 508 & 117 & 210 & 12 & 402 & 81 & 109 & 2181 \\
\hline $\begin{array}{l}\text { Ave } \\
\text { rage }\end{array}$ & 51 & 10 & 437 & 228 & 21 & 477 & 116 & 198 & 13 & 406 & 79 & 123 & 2159 \\
\hline
\end{tabular}

\subsection{Current State Value Stream Mapping}

Current State Value Stream Mapping is the first step to understanding the information and physical flow in the current BPJS outpatient health care process. The following is value stream mapping from the BPJS outpatient health service process:

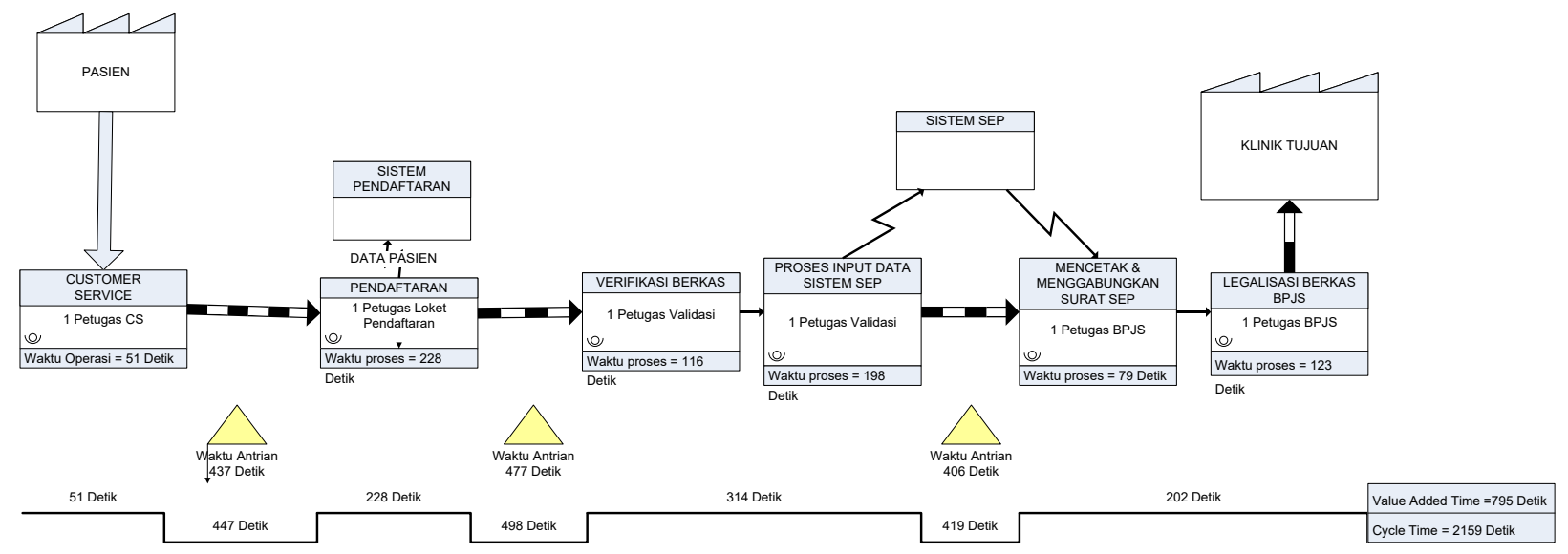

Figure 2. Current State Value Stream Mapping

Table 2. Value Stream Mapping Analysis

\begin{tabular}{|c|c|c|c|}
\hline No. & Indicators & CSVSM & Analysis \\
\hline 1. & $\begin{array}{l}\text { Time of } \\
\text { Effectivity }\end{array}$ & $\begin{array}{l}\text { Value Added Time: } \\
795 \text { seconds } \\
\text { Total Cycle Time: } \\
2159 \text { seconds } \\
\text { Process Cycle } \\
\text { Efficiency: } 36,79 \%\end{array}$ & $\begin{array}{l}\text { Based on BPJS Health outpatient service process, from the } \\
\text { entire process cycle time, activities that provide added value } \\
\text { is only } 795 \text { seconds or } 36.79 \% \text { of the entire process. }\end{array}$ \\
\hline 2. & $\begin{array}{l}\text { Flow of } \\
\text { Process }\end{array}$ & $\begin{array}{l}\text { The occurrence of a } \\
\text { bottleneck: } 1 \text {. At the } \\
\text { Registration Counter } \\
\text { 2. At the Validation } \\
\text { Counter 3. At the } \\
\text { Health BPJS Counter }\end{array}$ & $\begin{array}{l}\text { Bottlenecks that occur in the outpatient care process of BPJS } \\
\text { Health patients are located at each counter due to the large } \\
\text { number of patients who come not comparable to the number } \\
\text { of counters. At the registration counter, a bottleneck is caused } \\
\text { at the CS counter that is open } 30 \text { minutes early from the } \\
\text { registration counter so that patients arriving early accumulate } \\
\text { until the registration window opens. }\end{array}$ \\
\hline
\end{tabular}




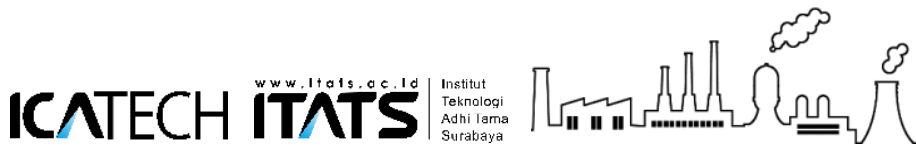

The $1^{\text {st }}$ International Conference on Advanced Engineering and Technology - 2018

\subsection{Value Stream Analysis Tools}

VALSAT is a tool used to facilitate understanding of existing value streams and facilitate understanding of existing value streams and make it easier to make improvements regarding waste contained in the value stream. VALSAT tool that will be selected based on 3 weight values that are above average. The results of the sequence of prioritized mapping tools are as follows:

Table 3. Value Stream Analysis Tools

\begin{tabular}{clcc}
\hline Ranking & Value Stream Analysis Tools & Total Weight & Description \\
\hline 1 & Process Activity Mapping & 41,6 & Selected \\
\hline 2 & $\begin{array}{l}\text { Supply Chain Response } \\
\text { Matrix }\end{array}$ & 28,02 & Selected \\
\hline 3 & Quality Filter Mapping & 16,36 & Selected \\
\hline 4 & Decision Point Analysis & 10,34 & $\begin{array}{c}\text { Not } \\
\text { Selected }\end{array}$ \\
\hline 5 & $\begin{array}{l}\text { Demand Amplification } \\
\text { Mapping }\end{array}$ & 9,51 & $\begin{array}{c}\text { Not } \\
\text { Selected }\end{array}$ \\
\hline 6 & Product Variety Funnel & 5,16 & $\begin{array}{c}\text { Not } \\
\text { Selected }\end{array}$ \\
\hline 7 & Physical Structure & $\begin{array}{c}\text { Not } \\
\text { Selected }\end{array}$ \\
& Average & 15,8 &
\end{tabular}

\subsection{Process Activity Mapping}

Process Activity Mapping (PAM) is a tool that is able to describe the detail stages of the service process that functions to evaluate which activities give added value or not so that the process runs more effectively and efficiently. In the process of BPJS outpatient health services there are 12 activities which can be seen in detail in the following table:

Table 4. Classification of activities from the Out Patient of Service Process in BPJS Health

\begin{tabular}{lccc}
\hline \multicolumn{1}{c}{ Classifications } & $\begin{array}{c}\text { Number of } \\
\text { Activity }\end{array}$ & $\begin{array}{c}\text { Time } \\
\text { (Seconds) }\end{array}$ & Prosentase \\
\hline Value Added Activity & 6 & 795 & $36,79 \%$ \\
\hline Non Value Added Activity & 3 & 1320 & $61,17 \%$ \\
\hline $\begin{array}{l}\text { Necessary but Non Value } \\
\text { Added }\end{array}$ & 3 & 44 & $2,04 \%$ \\
\hline \multicolumn{1}{c}{ Total } & 12 & 2159 & $100 \%$ \\
\hline
\end{tabular}

\subsection{Supply Chain Response Matrix}

Supply Chain Response Matrix (SCRM) in services is useful for evaluating facilities and services as well as the length of lead time in each area throughout the service process. The total ideal time obtained from the service process is 759 seconds and the actual time is 2159 seconds.

\subsection{Quality Filter Mapping}

Quality Filter Mapping (QFM) functions to identify the location of error problems in the service process. In this study, the process errors in the form of registration officers who are wrong in entering patient data so that they are required to re-register, error in the printer and run out of paper to print SEP so that customers are required to wait longer. 


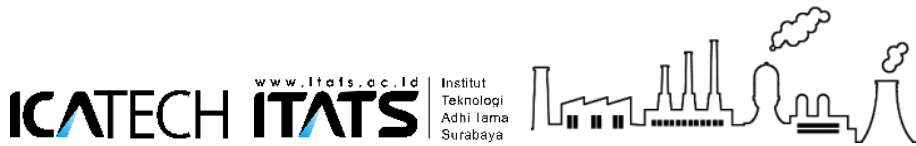

The $1^{\text {st }}$ International Conference on Advanced Engineering and Technology - 2018

Table 5. Data of BPJS Health of Outpatient Service Errors

\begin{tabular}{lccc}
\hline \multicolumn{1}{c}{ Periods } & Number of Patent & Fault & Prosentase (\%) \\
\hline February 2018 & 4575 & 14 & $0,3 \%$ \\
\hline March 2018 & 5611 & 6 & $0,1 \%$ \\
\hline April 2018 & 5453 & 19 & $0,34 \%$ \\
\hline May 2018 & 4824 & 11 & $0,23 \%$ \\
\hline \multicolumn{4}{c}{ Defect Rate } \\
\hline
\end{tabular}

Based on the data above, there are still errors in the service process that affect customer satisfaction. So that a number of decisions will be taken so that there will be an increase in service so that the service process will be better.

\subsection{Repair Recommendation Analysis}

Improvement recommendations are based on previous analyzes using Process Activity Mapping, Supply Chain Response Matrix, and Quality Filter Mapping. In this case, researchers have proposed several improvements in the process, so that the service process in the future will be more effective and efficient because the waste has been minimized. The following are recommendations for improvements related to elimination of non value added activities: The management takes the decision to merge the registration window, validation counter and BPJS Health counter, so that the registration process, file verification process, data input to the SEP system \& BPJS Health legalization are carried out at one counter. So that prospective patients just queue once at the registration counter, no longer need to queue at the validation counter and BPJS Health counter. Performing the counter clock work at the customer service counter, the previous customer service counter opens at 7:30 a.m., then the opening hours will be equal to $07: 30$ so there is no bottleneck at the registration counter. Increase the number of registration servers so that the bottleneck can be reduced.

To overcome the difference in ideal time and actual time in the service process. Then the hospital as a service provider will make improvements related to facilities and services, namely: (1) Increase the number of servers so that the bottleneck can be reduced; (2) Placing skilled apprentices so that errors can be minimized; (3) Conduct training related to the service process to officers related to services; (4) Add information boards so that patients are not confused with the completeness of the file. (5) Adding supporting facilities so that patients who are waiting feel comfortable. 6. Putting ATMs and Pharmacies in a close place so patients don't have to walk further.

\subsection{Future State Value Stream Mapping}

Based on the improvement recommendations that have been explained previously, it can be made lean service design through the future state value stream mapping in the process of outpatient BPJS health patient services as follows: 


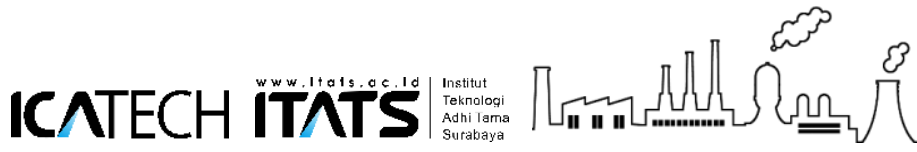

The $1^{\text {st }}$ International Conference on Advanced Engineering and Technology - 2018
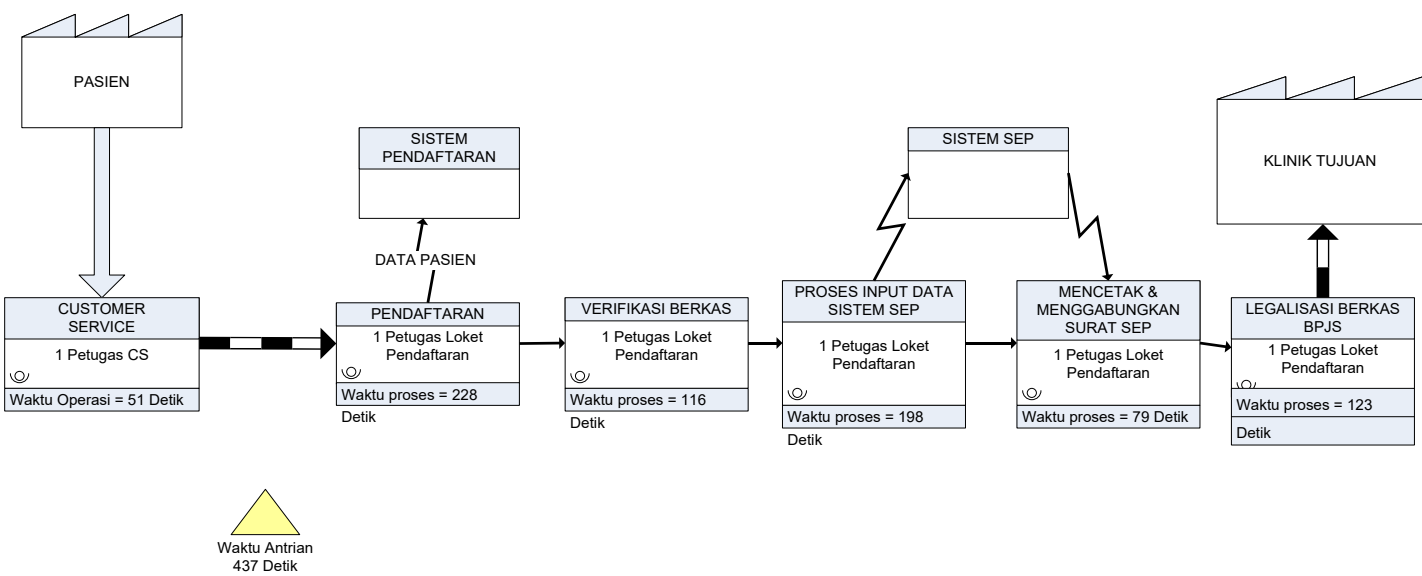

51 Detik

744 Detik

Figure 3. Future State Value Stream Mapping

Based on figure 4.8, it can be seen that the value added time is 795 seconds with the total cycle time in the entire process of 1242 seconds. Then the process cycle efficiency will be calculated, this is a way to see the efficiency in the process of outpatient services of BPJS Health patients after repairs. The following are the calculations:

$$
\begin{gathered}
\text { Process Cycle Efficiency }=\frac{\text { Value Added Time }}{\text { Cycle Time }} \times 100 \% \\
=\frac{795}{1242}=64 \%
\end{gathered}
$$

\subsection{Comparative Analysis Before and After Repair}

Based on the results of data processing, then compare activities before and after repairs. This is intended to find out changes that occur after repairs. The following is a comparison table on the flow of service processes before and after improvement:

Table 6. Comparisons Before and After Repairs

\begin{tabular}{lccc}
\hline \multicolumn{1}{c}{ Indikator } & Current State & Future State & Perubahan \\
\hline Value Added Activity & 795 seconds & 795 seconds & - \\
\hline Non Value Added Activity & 1320 seconds & 437 & 883 seconds \\
\hline Necessary Non Value Added Activity & 44 seconds & 10 seconds & 34 seconds \\
\hline Total cycle time & 2159 seconds & 1242 seconds & 916 seconds \\
\hline Process Cycle Efficiency & $36,79 \%$ & $64 \%$ & $27,21 \%$ \\
\hline
\end{tabular}

After repairs, a decrease in the cycle time is 2159 seconds to 1242 seconds. And the process cycle efficiency experienced a very significant increase, from $36.79 \%$ to $64 \%$. The difference between before repair and after repair is $27.21 \%$.

\section{Conclusion}

From the results of this study, obtained waste or waste conclusions that occur in the BPJS Outpatient Health Unit is a waste associated with unclear information, namely patients who do not understand the files needed so that patients are required to complete the file first so they cannot get service, then wait / delay related to the presence of a long patient queue at the counter so that patients have to wait a long time to get services, and defects related to the error of the counter in entering data so that patients have to repeat to fill in the data. The impact of implementing lean services on the service process of the 


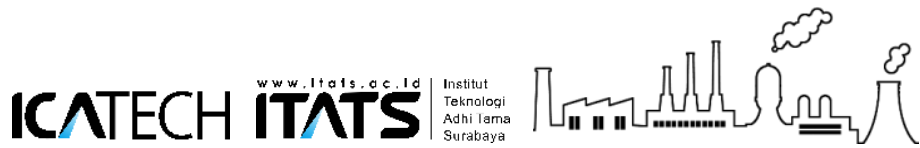

The $1^{\text {st }}$ International Conference on Advanced Engineering and Technology - 2018

Patient BPJS Patient Outpatient Unit Siti Khodijah Sepanjang's Branch Hospital is a more efficient patient service process. That is in the process cycle efficiency to be $64 \%$, which previously only amounted to $27.21 \%$ because there are still many wastes contained in the service process before the implementation of lean service.

\section{References}

[1] V. Gasperz, Lean Six Sigma for Manufacturing and Service Industries. Jakarta: Gramedia Pustaka Utama, 2007.

[2] V. Gaspers and A. Fontana, Lean Six sigma for manufactring and Service Industries. 2011.

[3] P. Hines and D. Taylor, "Going Lean," 2000.

[4] L. Michael and et al, The Lean Six Sigma Pocket Toolbook. New York: Mc Graw Hill, 2005.

[5] R. Prabowo, "Analisa Peningkatan Kualitas Produk Keramik Dengan Menggunakan Metode Six Sigma di CV. Glassmico Tile Tulungagung," J. IPTEK, 2012.

[6] P. Hines and N. Rich, "The seven value stream mapping tools," Int. J. Oper. Prod. Manag., vol. $17,1997$. 